\title{
THE SERVITUDES OF ENERGY FACILITIES - A SPECIFIC AND NECESSARY ELEMENT IN TERRITORY PLANNING
}

\author{
Gena Velkovska \\ Faculty of Economics, Trakia University of Stara Zagora \\ Studentski grad, 6000 Stara Zagora, Bulgaria \\ e-mail: gvelkovski@abv.bg
}

\begin{abstract}
The location of the servitude areas of energy facilities is specified by the general and detailed urban plans according to the location of the energy facilities: 1. In the towns and villages and settlements - in accordance with the terms and conditions of the Spatial Planning Act (SPA); 2. Outside towns and villages and settlements when agricultural land is involved - according to the terms and conditions of the Law for Protection of Agricultural Lands (LPAL) and the Bulgarian Regulations for Application of the Law for Protection of Agricultural Lands (BRALPAL); 3. Outside towns and villages and settlements when land in forest areas is involved - according to the terms and conditions of the Forest Act (FA); 4. In the protected areas - in accordance with the order for the declaration and plans for the management of protected areas under the terms and conditions of the Protected Areas Act; 5. In real estates - cultural values- according to the terms and conditions of the Cultural Heritage Act. A detailed plan is not required when the holder of the servitude builds new lines if their servitude falls entirely within the servitude area of already existing energy facilities. The regulation does not apply to the construction of site energy facilities. The dimensions of the servitude area of the energy facility are determined depending on: 1 . The type of the main energy of the facility - electricity or heat, as well as the type of energy resources; 2. The type of the energy facility - a site or route of a linear facility under the SPA; 3 . The way of laying lines and equipment - underground, ground, above ground (air), underwater; 4. The specific requirements to ensure the conditions for the construction or installing, the safe operation and maintenance of the energy facility or its separate parts and equipment; 5 . The requirement to ensure the smooth passage of people and equipment with specific dimensions, from the nearest street or road to all parts and equipment of the energy facility; 6 . The function of the land, involved with the servitude area; 7. The type and height of the plantations of perennial plants in the plot, involved with the servitude area. The servitude areas for underground and ground lines and facilities in towns and villages and settlements, located under streets and under/on sidewalks, can coincide with the servitude areas of other parallel or intersecting lines of the technical infrastructure.
\end{abstract}

Keywords: servitude, servitude area, energy facilities, territory planning, urban plan.

\section{INTRODUCTION}

Spatial planning in the Republic of Bulgaria is a state policy, through which, as stated in Article 1, Paragraph 1 of the Spatial Planning Act (SPA) [lex.bg], are ensured a sustainable development and favorable conditions for the life, work and recreation of the citizens of the country.

The major tools in the implementation of this policy are spatial planning and investment design.

Through the general urban plans is determined the main purpose of territories (Article 7, Paragraph 1 of SPA) while the detailed urban plans specify the designation of the landed properties (Article 8 of SPA), which has quite a wide range, including technical infrastructure. 


\section{ARTTIE $Y$}

Ipplied Resseirlohes in Technics, Technologies and Bductation

Journal of the Faculty of Technics and Technologies, Trakia University https://sites.google.com/a/trakia-uni.bg/artte/

Energy facilities are an essential component of the technical infrastructure and their construction and location, depending on the ownership of the landed property, require the exercise of servitude rights.

The servitudes of energy facilities, besides being an important and necessary element of spatial planning, possess specific characteristics which are subject to legal regulation.

In connection with what has been said so far, this publication deals precisely with those specifics of the servitudes of energy facilities in their capacity of a necessary element in the planning of the territories on which the energy facilities are built.

The main goal of the author is to present the important role of the servitudes of energy facilities as an element of spatial planning, based on some aspects of the current legal regulations in this area.

\section{SERVITUDES - A NECESSARY ELEMENT OF SPATIAL PLANNING}

Within the meaning of Article 64, Paragraph 2 of the Energy Act (EA) [lex.bg], servitudes are: - The right of way of people and equipment;

- The right to lay above ground and underground power lines, above ground and underground hydro-technical facilities to produce electricity and heat, gas pipelines, oil pipelines and petroleum product pipelines;

- The restrictions in the use of landed property, adjacent to the energy facilities.

\subsection{When do servitudes arise?}

Under Article 64, Paragraph 1 of the Energy Act, servitudes arise in the expansion of existing and the construction of new above ground and underground power lines, above ground and underground hydro-technical facilities to produce electricity and heat, gas pipelines, oil pipelines and petroleum product pipelines in favor of the persons who will build and operate the energy plant.

The emergence of servitudes is closely related to spatial planning, as they are an element of territory planning.

According to the wording of Article 64, Paragraph 4, Item 1 of the Energy Act, servitudes arise when there is an effective detailed urban plan, which determines the location of the relevant property.

As stated in Article 66 of the Energy Act, the type and location of the energy facilities and the areas of the servicing landed properties, included within the servitudes under this Act, are determined in the general and detailed plans.

How is the presence of a servitude on the territory secured?

There are two main directions in securing the servitudes with territory:

- Implementation of the appropriate expropriation procedures;

- Settlement of the right of way through the relevant property.

According to the wording of Article 62 of the Energy Act, when the construction or extension of site and/or linear energy facilities, as well as above ground and underground hydrotechnical facilities to produce electricity or parts thereof and the associated production facilities and disposal facilities for industrial waste, is carried out on state-owned property, the competent state authorities establish, in favor of the person who will build and operate the energy facility, the consideration right to build on the land, under the State Property Act without tender or competition.

When the construction or extension of the facilities is carried out on municipal property, the competent municipal authorities establish, in favor of the person who will build and operate the energy facility, the consideration right to build on the land under the Municipal Property Act without tender or competition.

IRTIIE Vol. 5, No. 1, 2017 ISSN 1314-8788 (print), ISSN 1314-8796 (online), doi: 10.15547/artte.2017.01.007 


\section{ARTTIE $Y$}

Ipplied Resseirlohes in Technics, Technologies and Bductation

Journal of the Faculty of Technics and Technologies, Trakia University https://sites.google.com/a/trakia-uni.bg/artte/

When it is necessary for the construction or extension of the site and/or linear energy facilities, as well as the above ground and underground hydro-technical facilities to produce electricity or parts thereof, to be carried out on private property, the relevant person must first acquire consideration ownership or the right to build on the land, necessary for the construction of the facility.

According to the regulations reflected in Article 192 of the SPA:

- The right of way through a foreign landed property is established by a written contract with notary certified signatures.

- Where no agreement has been reached between the owners of the landed property and another technical solution is obviously economically inexpedient, the right of way through the foreign landed property is established by order of the mayor of the municipality.

- The right of way through state-owned or municipal landed property is established, when another technical solution is obviously economically inexpedient, by order of the governor or by order of the mayor, respectively.

- The right of way should not result in deterioration in the conditions for development of the landed properties, prevention of the established way of permanent use of the landed property and it should not affect permitted constructions or existing buildings, unless explicitly agreed between the owners in the relevant contract .

- Deterioration in the conditions for development and use of state-owned or municipal land in establishing the right of way through other properties may be allowed in exceptional cases due to the lack of any technical ability or when another technical solution is obviously economically inexpedient, with the permission of the Minister of Regional Development and Public Works - for state-owned landed property or by a decision of the municipal council - for municipal land, respectively.

- The aforementioned contract and order are entered in the property register in the lot of the landed property, which is served by the established right of way, and in the lot of the landed property for which the right of way is established, the order being entered in the property register in the lot of the landed property, which is served by the established right of way, in the lot of the state-owned or municipal landed property, for which is established the right of way, and in the deed for the state-owned or municipal property.

\subsection{The right to lay deviations}

In Article 193 of the SPA are reflected specific regulations concerning the right to lay deviations from the main networks and facilities of the technical infrastructure in foreign real estate.

This right is established by a written contract between the owners of the landed property and with notary certified signatures, the contract giving the right to build and acquire ownership of the deviation from the main network of the technical infrastructure in the foreign property.

When no agreement has been reached between the owners of the landed property and another technical solution is obviously economically inexpedient, the right of laying is established by order of the mayor of the municipality.

The right to lay deviations from the main networks and facilities of the technical infrastructure in state-owned or municipal landed property is established, when another technical solution is obviously economically inexpedient, by order of the governor or order of the mayor, respectively.

The laying of deviations from the main networks and facilities of the technical infrastructure should not worsen the conditions for development of the landed properties, prevent the established way of permanent use of the landed property or affect permitted constructions or existing buildings, unless expressly agreed between the owners in their contract. 


\section{ARTTIE $Y$}

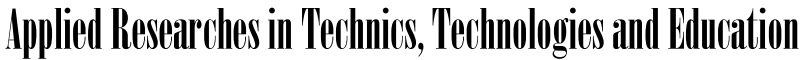

Journal of the Faculty of Technics and Technologies, Trakia University https://sites.google.com/a/trakia-uni.bg/artte/

Worsening of the conditions for development and use of state-owned or municipal land due to the laying of deviations from the main networks and facilities of the technical infrastructure in other properties may be allowed in exceptional cases due to the lack of any technical ability or when another technical solution is obviously economically inexpedient, with the permission of the Minister of Regional Development and Public Works - for state-owned landed property or by a decision of the municipal council - for municipal landed property, respectively.

The contract and the order are entered in the property register in the lot of the landed property, which is served by the established right to lay deviations from the main networks and facilities of the technical infrastructure and in the lot of the landed property in which the deviations from the main networks and facilities of the technical infrastructure are laid while the order is entered in the property register in the lot of the landed property, which is served by the established right to lay deviations from the main networks and facilities of the technical infrastructure, in the lot of the state-owned or municipal landed property in which the deviations from the main networks and facilities of the technical infrastructure are laid and in the deed for state-owned or municipal property.

The wording of Article 68 of the Energy Act regulates the legal protection of servitude exercised, namely:

- When the owner, user or lessee of the property carries out unauthorized building development, enclosure, planting or other violation of the regime of exercising servitude, the holder of the servitude has the right to refer to the competent authorities with a request to remove the illegal construction at the expense of the owner, user or lessee if the latter fails to remove them within the deadline, given by the holder of the servitude.

- In such cases the holder of the servitude does not owe compensation for the damage caused.

\subsection{Servitudes - a necessary mechanism in the effective functioning of technical infrastructure}

Servitudes are an important and necessary mechanism in the effective functioning of the technical infrastructure.

According to the wording of Article 64 Paragraph 1 of the SPA technical infrastructure also includes the following elements:

- The transmission lines (networks) and related facilities in an unregulated area (item 2);

- The transmission lines (networks) and related facilities in a regulated area (item 3);

- The distribution lines and systems and related facilities (transformer stations, electrical substations, water treatment plants for drinking and waste waters, distribution stations, etc.), including the connecting lines to the buildings' systems and common measurement tools (p.4);

Within the meaning of Paragraph 2 of the aforesaid Article 64 of the SPA, the technical infrastructure elements are provided with urban plans, an integral part of the general and detailed urban plans being the plan schemes of the elements of the technical infrastructure.

According to the text of Article 67, Paragraphs 1 and 2 of the SPA, underground and above ground common networks and facilities of the technical infrastructure are designed and constructed in municipal and state-owned land, and when this is impossible, the networks and facilities of the technical infrastructure are built on landed property, owned by physical and legal persons pursuant to Article 199 or 205 of the SPA.

What legal regulation is reflected in the wording of Article 199 of the SPA?

The state and municipality are entitled to priority over third parties in buying a property at market prices in the cases when a facility is to be built on the property, under a detailed plan, and this facility will be public state or public municipal property.

IRTIIE Vol. 5, No. 1, 2017 ISSN 1314-8788 (print), ISSN 1314-8796 (online), doi: 10.15547/artte.2017.01.007 


\section{ART'TE \\ ( \\ Ipplied Resseirlohes in Technics, Technologies and Bductation \\ Journal of the Faculty of Technics and Technologies, Trakia University \\ https://sites.google.com/a/trakia-uni.bg/artte/}

The owner can sell the property or parts of it to a third party only after he has offered it for purchase to the state or municipality, depending on the provisions of the detailed urban plan and after he has submitted a written refusal to the notary.

The refusal should state the conditions under which the purchase was proposed.

Within the meaning of Article 205, item 2 of the SPA, based on effective detailed plans, real estate which is the property of legal or physical persons may be expropriated pursuant to the State Property Act and the Municipal Property Act for facilities with public ownership of the state and municipalities, as follows:

a) For the construction and reconstruction of the transport technical infrastructure, the reconstruction of transport and communication networks and facilities - roads, streets, alleys, squares, above ground and underground tracks of railway and tramway lines and related facilities;

b) For the construction and reconstruction of other networks and facilities of the technical infrastructure - water supply, sewerage, water and wastewater treatment, electricity, heating, gas, electronic communication networks, etc.;

In the landed properties that are located over or near underground communications or other networks and facilities of the technical infrastructure such a development is projected as would not adversely affect the constructions of the technical infrastructure and not go into the servitude strips, necessary for the operation and repair of that infrastructure.

In case it is impossible to achieve appropriate development or the servitude strips occupy more than $1 / 3$ of the area of the regulated landed property, the detailed plan provides the property for the relevant network, the expropriation being carried out at the expense of the owner of the network or facility in compliance with the legal requirements, stipulated in the SPA.

\section{SPECIFIC FEATURES OF THE SERVITUDE ZONE}

According to the requirement of Article 3 of Ordinance № 16 dated 9 June 2004 for the servitudes of energy facilities [lex.bg], the special regime for the exercise of servitude rights is applied in the servitude zone around the energy facility.

The location and dimensions of the servitude zones are regulated in detail in Chapter Two of the abovementioned Ordinance No. 16.

\subsection{Location of the servitude zones}

The location of the servitude zones is determined by the general and detailed plans according to the location of the energy facilities and on this basis according to the current regulations for the different territories, namely:

a) In residential areas and settlements - according to the terms and conditions of the SPA;

b) Outside residential areas and settlements when agricultural land is concerned - according to the terms and conditions of the Law for Protection of Agricultural Lands (LPAL) and the Regulations for Implementing the Law on Protection of Agricultural Lands (RILPAL);

c) Outside residential areas and settlements when land in forest areas is concerned according to the terms and conditions of the Forestry Act (FA);

d) In protected areas - in accordance with the order for declaration and the plans for management of protected areas under the terms and conditions of the Protected Territories Act (PTA);

e) In real estates that are cultural values - under the terms and conditions of the Cultural Heritage Act (CHA). 


\section{IRITIE Ipplied Researrohes in Technics, Technologies and Bductition Journal of the Faculty of Technics and Technologies, Trakia University https://sites.google.com/a/trakia-uni.bg/artte/}

\subsection{Dimensions of the servitude zones}

The wording of Article 6, Paragraph 1 of Ordinance № 16 regulates the seven criteria which determine (on which depend) the dimensions of the servitude zone of the energy facility. These criteria are:

a) The type of energy, basic for the facility - electricity or heat, as well as the type of energy resources;

b) The type of energy facility - site or route of a linear facility under the SPA;

c) The way of laying pipes and equipment - underground, ground, above ground (air) underwater;

d) The specific requirements to ensure conditions for the construction or laying, the safe operation and maintenance of the energy facility or its separate parts and equipment;

e) The requirement to ensure the smooth passage of people and equipment of specific dimensions, from the nearest street or road to all parts and equipment of the energy facility;

f) The designation of the landed property which the servitude zone concerns;

g) The type and height of the perennial plantations in the landed property which the servitude zone concerns.

The servitude zones for above ground and underground pipes and facilities in residential areas and settlements, located under streets and under/over sidewalks can coincide with the servitude zones of other parallel or intersecting route lines of the technical infrastructure.

\section{CONCLUSION}

Based on what has been said so far we can summarize that servitudes, servitude zones respectively, are a function of spatial planning and investment design.

That capacity of theirs is secured in a number of wordings of the relevant legislation and above all in the SPA and the EA.

For example, the wording of Article 112, Paragraph 2 of item 10, states that a detailed plan regulates the networks and facilities of the technical infrastructure with their servitude strips, as well as the facilities, related to the protection of the environment;

According to the wording of Article 66 of the EA, the type and location of energy facilities and the areas of the serving landed properties, included within the servitudes under this Act are determined in the general and detailed plans.

The location of the networks and facilities of the technical infrastructure within the meaning of Article 114, Paragraph 2 of the SPA is determined by the investment design.

Without any claims of having exhausted the subject, the author makes the following statements:

Overall, the regulations relating to the servitudes of energy facilities are good, nevertheless it is necessary to specify some texts in the following areas:

a) The legal protection of the servitudes of energy facilities, considering the importance of this kind of technical infrastructure (for example the wording of Article 68, Paragraphs 1 and 2 of the EA states that when the owner, user or lessee of the property carries out an unauthorized building development, enclosure, planting or other violation of the regime of exercising a servitude, the holder of the servitude has the right to refer to the competent authorities with a request to remove the illegal construction at the expense of the owner, user or lessee if the latter fails to remove them within the time limit given by the holder of the servitude. In such cases the holder of the servitude does not owe compensation for damages);

b) The improvement of the methodology in assessing the right to compensation that has arisen. As legal practice has shown, this compensation is often the subject of litigation (Article 64, Paragraph 6 of the EA and Articles 210 and 211 of the SPA, etc.).

\section{IRTIIE Vol. 5, No. 1, 2017 ISSN 1314-8788 (print), ISSN 1314-8796 (online), doi: 10.15547/artte.2017.01.007}




\section{IDTTE C Journal of the Faculty of Technics and Technologies, Trakia University https://sites.google.com/a/trakia-uni.bg/artte/}

\section{REFERENCES}

[1] Spatial Planning Act, effective from March 31, 2001, amended and supplemented State Gazette, No 51 of July 5, 2016.

[2] Energy Act, promulgated SG No 107 of December 9, 2003 amended and supplemented SG No 47 of June 21, 2016.

[3] Ordinance 16 of June 09, 2004 for the servitudes of energy facilities, issued by the Ministry of Energy and Energy Resources, the Ministry of Agriculture and Forestry and the Ministry of Regional Development and Public Works; SG issue 88 of October 8, 2004 amended and supplemented SG 75 of September 29, 2015.

[4] www.lex.bg. 